\title{
Repurposing multi-targeting plant natural product scaffolds in silico against SARS- CoV-2 non-structural proteins implicated in viral pathogenesis
}

Von Novi O. de Leon ${ }^{1,2}$, Joe Anthony H. Manzano ${ }^{1,2}$, Delfin Yñigo H. Pilapil IV ${ }^{1,2}$, Rey Arturo T. Fernandez ${ }^{1}$, James Kyle Anthony R. Ching ${ }^{1,3}$, Mark Tristan J. Quimque ${ }^{1,4,5}$, Kin Israel R. Notarte ${ }^{6}$, and Allan Patrick G. Macabeo ${ }^{1^{*}}$

${ }^{1}$ Laboratory for Organic Reactivity, Discovery and Synthesis (LORDS), Research Center for the Natural and Applied

Sciences, University of Santo Tomas, España Blvd., 1015 Manila

${ }^{2}$ Department of Biological Sciences, College of Science, University of Santo Tomas, Espana Blvd., Manila 1015,

Philippines

${ }^{3}$ Department of Chemistry, College of Science, University of Santo Tomas, Espana Blvd., Manila 1015, Philippines

${ }^{4}$ The Graduate School, University of Santo Tomas, Espana Blvd., Manila 1015, Philippines

${ }^{5}$ Chemistry Department, College of Science and Mathematics, Mindanao State University - Iligan Institute of

Technology, Tibanga, 9200 lligan City, Philippines

${ }^{6}$ Faculty of Medicine and Surgery, University of Santo Tomas, Espana Blvd., Manila 1015, Philippines

${ }^{*}$ Correspondence:

Phone numbers: +632-3406-1611 extension 4057

Facsimile numbers: $+632-8731-4031$

E-mail address: apgmacabeo@ust.edu.ph 
Abstract:

Background: Accessing COVID-19 vaccines is a challenge despite successful clinical trials. This burdens the COVID-19 treatment gap, thereby requiring accelerated discovery of anti-SARSCoV-2 agents. Thus, this study explored the potential of anti-HIV reverse transcriptase (RT) phytochemicals as inhibitors of SARS-CoV-2 non-structural proteins (nsps) by targeting in silico key sites in the structures of SARS-CoV-2 nsps. Moreover, structures of the anti-HIV compounds were considered for druggability and toxicity. 104 anti-HIV phytochemicals were subjected to molecular docking with papain-like protease (nsp3), 3-chymotrypsin-like protease (nsp5), RNAdependent RNA polymerase (nsp12), helicase (nsp13), SAM-dependent 2'-O-methyltransferase (nsp16) and its cofactor (nsp10), and endoribonuclease (nsp15). Drug-likeness and ADME (absorption, distribution, metabolism, and excretion) properties of the top ten compounds per nsp were predicted using SwissADME. Their toxicity was also determined using OSIRIS Property Explorer.

Results: Among the twenty-seven top-scoring compounds, the polyphenolic natural products amentoflavone (1), robustaflavone (4), punicalin (9), volkensiflavone (11), rhusflavanone (13), morelloflavone (14), hinokiflavone (15), and michellamine B (19) were multi-targeting and had the strongest affinities to at least two of the nsps (Binding Energy $=-7.7$ to $-10.8 \mathrm{kcal} / \mathrm{mol}$ ). Friedelin (2), pomolic acid (5), ursolic acid (10), garcisaterpenes A (12), hinokiflavone (15), and digitoxigenin-3-O-glucoside (17) were computationally druggable. Moreover, compounds 5 and 17 showed good gastrointestinal absorptive property. Most of the compounds were also predicted to be non-toxic.

Conclusions: Twenty anti-HIV RT phytochemicals showed multi-targeting inhibitory potential against SARS-CoV-2 nsp3, 5, 10, 12, 13, 15, and 16, and can therefore be used as prototypes for anti-COVID-19 drug design. 
Background:

The rapid spread of the severe acute respiratory syndrome coronavirus 2 (SARS-CoV-2) marks itself as one of the deadliest viruses in recent history due to high mortality and morbidity rates [1, 2]. As of February 2021, the World Health Organization recorded over one hundred and five million cases worldwide with 2.4 million deaths [3]. Continuous efforts are being carried out to unravel the pathophysiology of the virus as well as the pursuit to develop efficacious vaccines and antiviral drugs to combat this pandemic. Recently, several COVID-19 vaccines have been approved for deployment and administration in developed countries. While this presents a step forward towards the mitigation and control of the outbreak, the demand for effective antiviral drugs against SARS-CoV-2 remains irrefutable as promising treatment towards emerging COVID-19 cases. In addition, they may be further developed as therapeutic regimens to subjects with a higher risk of exposure as well as to poor vaccine responders $[4,5]$.

To develop SARS-CoV-2 targeting drugs, identification of drug targets is essential. SARSCoV-2 is a betacoronavirus that has an enveloped, positive-sense, single-stranded RNA that encodes structural, non-structural (nsps), and accessory proteins [6]. Among possible drug targets, nsps are highly favored because they function during viral genome replication and posttranslational mechanisms which ultimately strengthens virulence and pathogenesis [7]. Although any of the sixteen nsps could be utilized as possible drug targets, the availability of crystal structure along with their vital role in infection, accelerate and enhance the chances of success of anti-COVID-19 drug discovery and development [8].

Natural products are a prolific source of secondary metabolites that are molecular inspirations for drugs, which may have elevated pharmacologic properties and minimal side effects, against viral infections [5, 9-11]. To date, numerous efforts describing the potential of secondary metabolites from various sources as SARS-CoV-2 protein inhibitors especially against 
3-chymotrypsin-like cysteine protease (3CL pro) and RNA-dependent-RNA-polymerase (RdRp) have been reported [5, 12-17].

The growing interest to explore the potential of natural products as multi-targeting antagonists of SARS-CoV-2 non-structural proteins led us to repurpose previously reported antiHIV reverse transcriptase (RT) natural products using molecular docking studies. SARS-CoV-2 and the human immunodeficiency virus (HIV) are single-stranded RNA viruses that utilize RNAdependent polymerases and code precursor polyproteins vital for their respective pathogenesis. Thus, we computationally interrogated 104 known anti-HIV RT phytochemicals against seven core viral target proteins namely nsp3 (PLpro), nsp5 (3CLpro), nsp12 (RdRp), nsp13 (helicase), nsp15 (endoribonuclease), and nsp16-nsp10 complex (S-adenosylmethionine complex). Druglikeness as well as the ADMET (absorption, distribution, metabolism, excretion, and toxicity) characteristics of the top-ranked ligands were also predicted to determine their druggability and toxicity risks. 
Methods:

Target enzyme preparation

Seven target enzymes with important functions in SARS-CoV-2 infectivity were selected and obtained from the Protein Data Bank (PDB): 3CLpro (PDB ID: 6LU7), PLpro (PDB ID: 6W9C), RdRp (PDB ID: 6M71), helicase (6JYT), nsp 10/16 complex (6W4H), and nsp15 (6VWW). These proteins in three-dimensional structures were added to UCSF Chimera 1.14 platform as PDB files [18]. All proteins belong to SARS-CoV-2 except for helicase due to unavailability of nsp13. Thus, helicase model from SARS-CoV-1 which shares $99.8 \%$ sequence identity and $100 \%$ sequence similarity with that of SARS-CoV-2 was used [19]. Coronavirus helicase domains are distinct compared to other (+)-sense RNA virus domains due to presence of linkage in a single protein to a binuclear zinc-binding domain at the $\mathrm{N}$-terminus. This domain is composed of 12 conserved cysteine-histidine residues and is a good target in antiviral drug discovery [20-22].

\section{Ligand selection and preparation}

A total of 104 plant secondary metabolites (Supplementary Figure 1; Supplementary Table 1) previously reported to inhibit HIV [23] were used as ligands targeting the above-mentioned viral proteins. The plant metabolite structures were formatted as SYBYL mol2 file or in SMILES notation using Avogadro (version 1.20) and were added to the UCSF Chimera 1.14 platform [24].

\section{Molecular docking simulations}

Molecular docking experiments were carried out on UCSF Chimera 1.14 platform [18]. Protein structures in three dimensions were opened in PDB formats. Co-crystallized ligands and other molecules were removed from the crystallized protein. Ligands were added in the platform 
as SYBYL mol2 files or in SMILES notation. Ligand and protein structures were minimized through addition of missing hydrogen atoms and charges to the structures using the Gasteiger charge method, which was computed using Amber's Antechamber module [25]. 'Flexible ligand into flexible active site' protocol was followed during execution of docking procedures. In this protocol, flexible ligands were allowed and positioned within a grid box which encompasses the enzymatic ligand-binding cavity, as predicted using $\mathrm{COACH}$ algorithms [26].

Druggability, ADME, and toxicity prediction

Absorption, distribution, metabolism and excretion (ADME) properties of top twenty-seven compounds were computationally predicted using SwissADME software. Evaluation of pharmacokinetic profiles of compounds were performed according to Lipinski's 'rule of five' which assesses biochemical properties of a drug candidate involved in permeation and cell absorption. Three of the following values need to be met according to Lipinski's criteria: $<500$ Daltons (Da) for molecular weight, $<5$ for calculated lipophilicity $(\log P),<10$ for the number of hydrogen-bond acceptors, and $<5$ for the number of hydrogen bond donors [27]. Moreover, toxicity of hit compounds, specifically mutagenicity, tumorigenicity, reproductive toxicity, and irritant effects, were predicted in silico using OSIRIS Property Explorer software [28][16]. Solubility (Log S) was also predicted using the same software in which Log $S \geq-4$ indicates good solubility and favorable absorption of compounds. 
Results:

Target enzymes

The targeted nsps were classified according to their major functions in the SARS-CoV-2 life cycle, specifically autolytic processing, viral replication, and host immunity evasion. The cysteine proteases, PLpro and 3CLpro, function in the proteolytic cleavage of the replicase polyproteins into individual nsps. RdRp and helicase are components of the replicationtranscription complex vital for SARS-CoV-2 proliferation. The SAM-dependent 2'-Omethyltransferase in complex with nsp10 as its cofactor provides a 5' cap to the RNA genome through C2'-O-methyl-ribosyladenine, conferring RNA stability and host cell immunity protection. Lastly, the endoribonuclease hinders recognition of dsRNA intermediates by host dsRNA sensors.

Ligand selection and molecular docking

104 repurposed anti-HIV reverse transcriptase phytochemicals against SARS-CoV-2 nsps comprised of polyphenolics, terpenoids, alcohols, and alkaloids were docked with nsps3, 5, 10, $12,13,15$, and 16 . Twenty-seven compounds showed favorable binding affinities while twenty exhibited multi-targeting properties (Figure 1). 

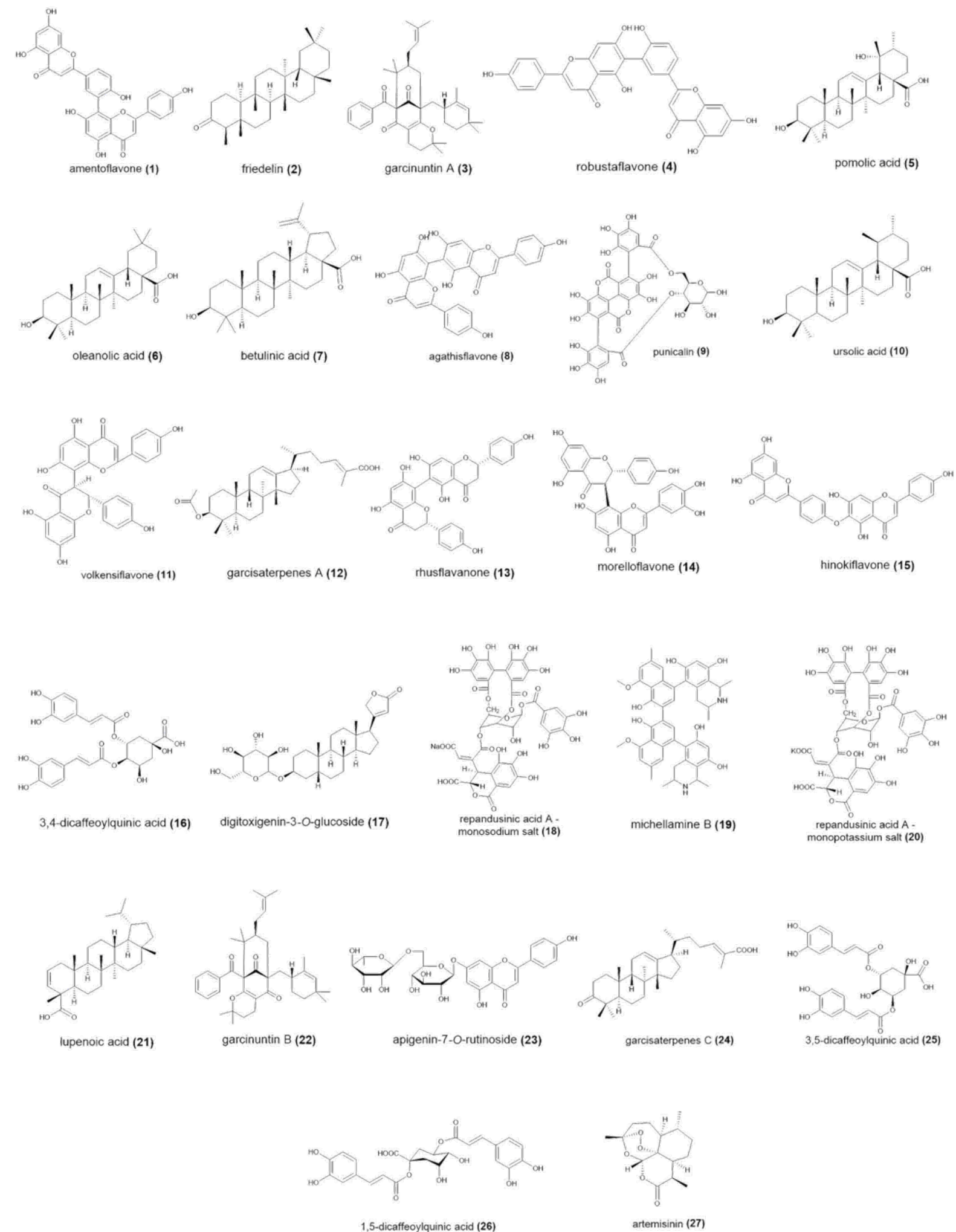

Figure 1 Anti-HIV RT phytochemicals with strong binding affinities to at least one of the target nsps 
Molecular docking with autolytic-processing enzymes (nsp3 and nsp5)

Top ten compounds against PLpro exhibited binding affinities of -10.1 to $-10.8 \mathrm{kcal} / \mathrm{mol}$, which is relatively stronger compared to the binding energy $(B E)$ of $-6.9 \mathrm{kcal} / \mathrm{mol}$ of the reference drug, lopinavir [16] (Table 1). The biflavonoid amentoflavone (1) exhibited highest affinity to PLpro with its benzopyrone (ring $\mathrm{C}$ ) and phenolic moiety (ring B) participating through $\mathrm{H}$-bonding and pianion interactions with Lys711, respectively (Figure 2A). Ring C additionally bound lle580 through pi-alkyl interaction. The phenolic functionality in ring B also participated in hydrogen bonding with His342 and in pi-alkyl binding with Ala579 and Leu742. Ring A' of the benzopyrone moiety bound Arg712 by $\mathrm{H}$-bonding and lle310 by pi-alkyl interaction. Meanwhile, the phenolic moiety (ring B') exhibited pi-anion interaction with Asp339 and pi-cation interaction with Arg558.

On the other hand, top-ranked ligands against 3CLpro exhibited binding affinities of -7.9 to $-8.6 \mathrm{kcal} / \mathrm{mol}$, which is stronger than the $\mathrm{BE}$ of $-7.6 \mathrm{kcal} / \mathrm{mol}$ of lopinavir [16] (Table 1). The biflavones amentoflavone (1) and volkensiflavone (11) showed highest affinity to 3CLpro (Figure 2B). The chromanone moieties (rings A' and C) of amentoflavone showed stacked amide-pi and pi-pi T-shaped interactions with His41, a component of the 3CLpro catalytic dyad. These interactions were also demonstrated by its phenolic moiety to Asn 142 . The chromanone moiety (rings $\mathrm{A}$ and $\mathrm{C}$ ) was bound to Met165 through pi-alkyl interaction along with hydrogen bonds with Val186, Arg188, and Glu166. Ring A' also bound Cys44 through H-bonding. Volkensiflavone (11) was likewise bound to the 3CLpro catalytic dyad, His41 and Cys145, through pi-anion interaction and hydrogen bonding of the chromanone moieties (rings $C$ and $A^{\prime}$ respectively). Moreover, rings A' of the flavone substructure also exhibited hydrogen bonding with Glu166 while the B ring residue bound Thr25 through a pi-sigma interaction. 
Table 1 Binding affinities and interactions of top ten ligands against the cysteine proteases

\begin{tabular}{|c|c|c|c|c|}
\hline Target & Cpd & Binding affinity & Hydrogen bonds & Other interactions \\
\hline \multirow[t]{10}{*}{ PLpro } & 1 & -10.8 & $\begin{array}{l}\text { His342, Lys711, } \\
\text { Arg712 }\end{array}$ & $\begin{array}{c}\text { Lys711, Asp339, Arg558, } \\
\text { Ile310, Ile580, Ala579, } \\
\text { Leu742 }\end{array}$ \\
\hline & 2 & -10.7 & None & $\begin{array}{l}\text { His342, Leu557, Ala579, } \\
\text { Leu742 }\end{array}$ \\
\hline & 3 & -10.7 & Lys711, Arg712 & $\begin{array}{l}\text { Ile310, Ala338, His342, } \\
\text { Leu557, Ala579, Ile580, } \\
\text { Val635, Lys694, Arg712 }\end{array}$ \\
\hline & 4 & -10.6 & $\begin{array}{c}\text { Thr583, Arg586, } \\
\text { Tyr634 }\end{array}$ & $\begin{array}{l}\text { Asp339, Arg558, Ala579, } \\
\text { lle580, Met630, Leu742 }\end{array}$ \\
\hline & 5 & -10.4 & Val659 & $\begin{array}{l}\text { Leu557, Arg558, Met560, } \\
\text { Ala579, Ile580, Leu742 }\end{array}$ \\
\hline & 6 & -10.3 & Asp226 & None \\
\hline & 7 & -10.2 & Lys711, Arg712 & None \\
\hline & 8 & -10.2 & $\begin{array}{c}\text { Asp339, Arg586, } \\
\text { Tyr634 }\end{array}$ & $\begin{array}{c}\text { Val304, Ala338, Asp339, } \\
\text { Arg558, Ala579, Lys711, } \\
\text { Leu742 }\end{array}$ \\
\hline & 9 & -10.2 & $\begin{array}{l}\text { Gly337, Asp339, } \\
\text { Arg345, Arg558, } \\
\text { Arg712 }\end{array}$ & Ile310 \\
\hline & 10 & -10.1 & $\begin{array}{c}\text { Asp339, Arg345, } \\
\text { Tyr634 }\end{array}$ & $\begin{array}{l}\text { Leu557, Ile580, Met630, } \\
\text { Val635, Lys711, Leu741 }\end{array}$ \\
\hline \multirow[t]{11}{*}{ 3CLpro } & 1 & -8.6 & $\begin{array}{l}\text { Cys44, Val186, } \\
\text { Arg188, Glu166 }\end{array}$ & $\begin{array}{l}\text { Thr25, His41, Asn142, } \\
\text { Cys145, Met165 }\end{array}$ \\
\hline & 11 & -8.6 & Cys145, Glu166 & Thr25, His41 \\
\hline & 12 & -8.5 & $\begin{array}{l}\text { Thr24, Ser46, Thr190, } \\
\text { Gln192 }\end{array}$ & Thr25, His41 \\
\hline & 13 & -8.5 & Thr26, His41 & Met49, Pro168 \\
\hline & 4 & -8.5 & Arg188, Gln189 & None \\
\hline & 8 & -8.4 & Thr26, Gln189, Thr190 & $\begin{array}{l}\text { Leu27, Met49, Glu166, } \\
\text { Met165, Pro168 }\end{array}$ \\
\hline & 14 & -8.4 & $\begin{array}{l}\text { Phe140, Gly143, } \\
\text { Arg188, Gln189 }\end{array}$ & His41 \\
\hline & 15 & -8.1 & Asn119, Val186 & None \\
\hline & 16 & -7.9 & $\begin{array}{l}\text { Gly143, Cys145, } \\
\text { Glu166, GIn189 }\end{array}$ & His41, Gln189 \\
\hline & 17 & -7.9 & His41, Asn119 & His41, Gly143, His163 \\
\hline & 3 & -7.9 & His41 & Leu27, His41 \\
\hline
\end{tabular}


(A)

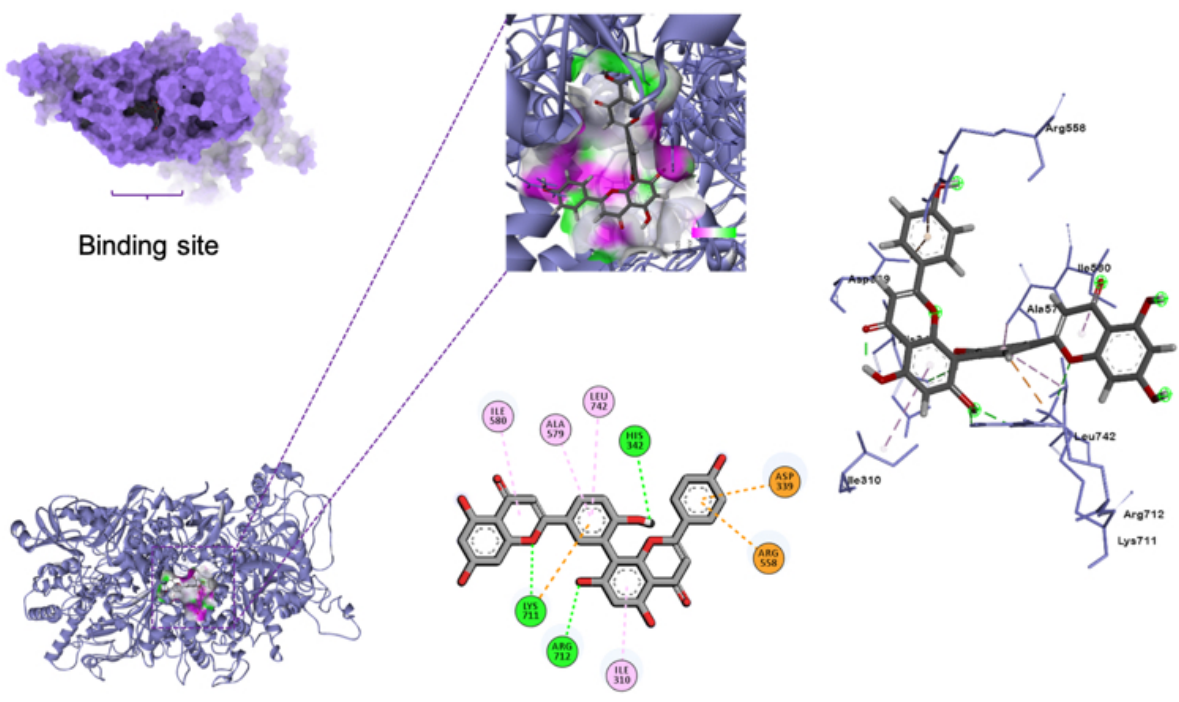

(B)
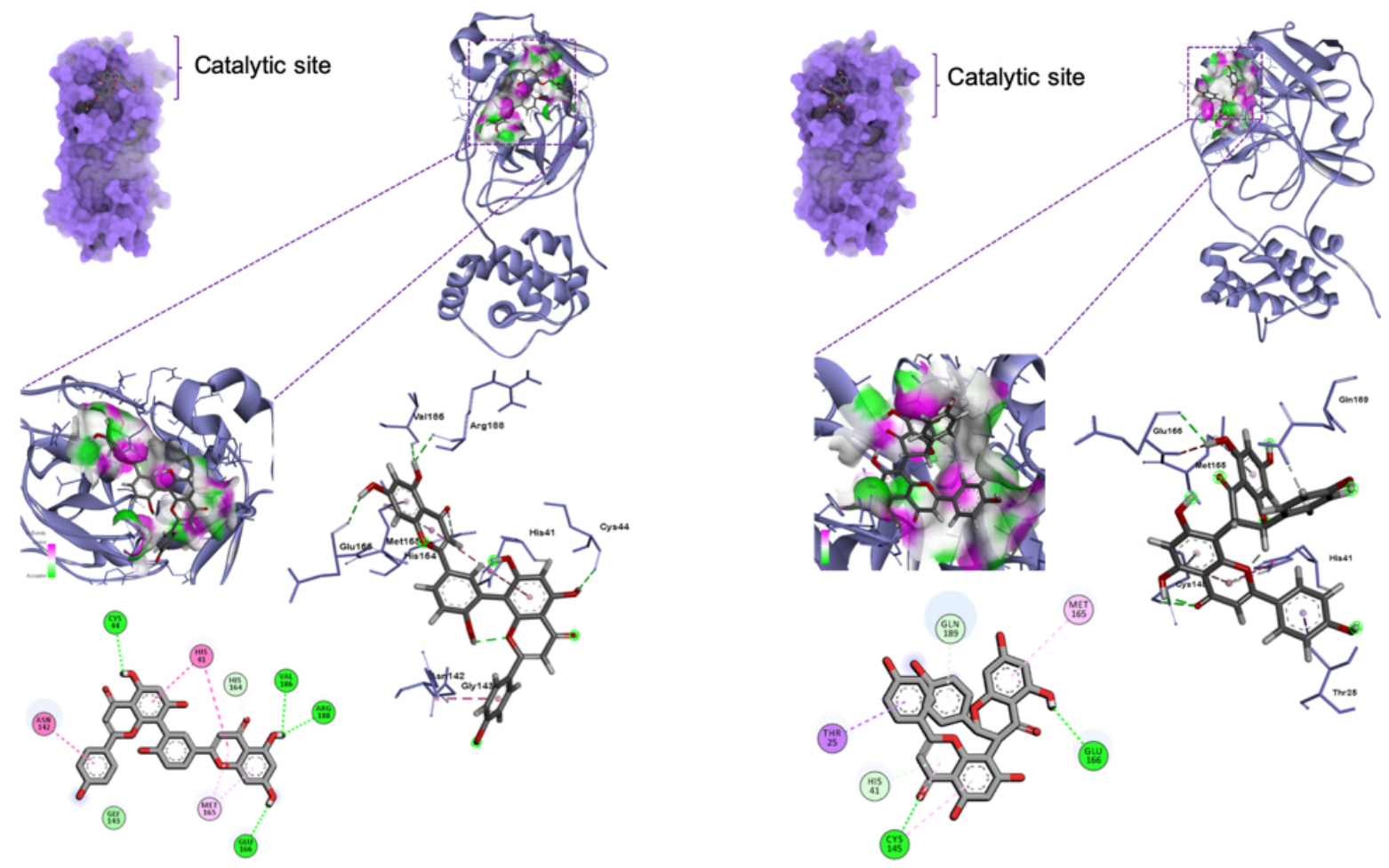

Figure 2 Top 1-binding compounds in complex with their target cysteine proteases: (A) amentoflavone (1) in complex with PLpro, (B) amentoflavone (1) (left) and volkensiflavone (11) (right) in complex with 3CLpro 
Molecular docking with replication-transcription complex enzymes (nsp12 and nsp13)

Among the top ten compounds against RdRp with binding affinities of -8.6 to $-9.5 \mathrm{kcal} / \mathrm{mol}$, the ellagitannin punicalin (9) exhibited the highest affinity (Table 2; Figure 3A). This BE is lower than $-7.6 \mathrm{kcal} / \mathrm{mol}$ of the reference drug favipiravir [16]. The ellagic acid moiety occupied lle494 and its galloyl hydroxyl bound Asn497, which are both components of the RdRp finger domain that is responsible for the entry and exit of the RNA template during replication-transcription [29]. Moreover, its glucose hydroxyl and hydrogen participated in hydrogen bonding and carbonhydrogen bonding respectively with Asp684, a component of the motif B of the polymerase active site [30]. Other interactions include the participation of its ellagic acid moiety in pi-alkyl interaction with Lys577, galloyl hydroxyl in hydrogen bonding with Gly590, carbonyl oxygen in hydrogen bonding Tyr689, and glucose moiety in carbon-hydrogen bonding with Ala685.

Meanwhile, the top-ranked ligands against helicase had binding affinities of -8.4 to -9.2 $\mathrm{kcal} / \mathrm{mol}$ in which the biflavonoids rhusflavanone (13) and morelloflavone (14) exhibited the strongest affinity, comparable to the reference drug cepharanthine with BE of $-10.3 \mathrm{kcal} / \mathrm{mol}$ [31] (Figure 3B). Compound 13 occupied the helicase Rec1A domain, which is a component of the nucleotide binding site, through hydrogen bonding of its chromanone (ring A') hydroxyl and pyrone (ring C') oxygen with Lys288 and Ala316, respectively [31]; pi-alkyl interactions of its chromene moieties, rings A with Ala316 with Ala316 and ring A' with Lys320; and pi-cation interaction of its hydroxyphenyl moiety (ring B) with Lys320. 
Table 2 Binding affinities and interactions of top ten ligands against the nsps vital for replication

\begin{tabular}{|c|c|c|c|c|}
\hline Target & Cpd & $\begin{array}{l}\text { Binding } \\
\text { Affinity }\end{array}$ & Hydrogen bonds & Other interactions \\
\hline \multirow[t]{12}{*}{$\mathrm{RdRp}$} & 9 & -9.5 & $\begin{array}{l}\text { Asn497, Gly590, } \\
\text { Asp684, Tyr689 }\end{array}$ & Ile494, Lys577, Asp684, Ala685 \\
\hline & 10 & -9.1 & Val495 & Ile494, Lys577, Ala580, Ala685 \\
\hline & 2 & -8.9 & None & $\begin{array}{c}\text { Ile494, Arg569, Leu576, Lys577, } \\
\text { Ala685 }\end{array}$ \\
\hline & 15 & -8.9 & $\begin{array}{l}\text { Asn496, Asn497, } \\
\text { Arg569, Ala685 }\end{array}$ & $\begin{array}{c}\text { Ile494, Lys500, Lys577, Ala580, } \\
\text { Ala685 }\end{array}$ \\
\hline & 18 & -8.9 & $\begin{array}{l}\text { Asn496, Arg569, } \\
\text { Ala685, Ser759 }\end{array}$ & Lys545, Arg569 \\
\hline & 19 & -8.8 & $\begin{array}{l}\text { Ile548, Lys593, } \\
\text { Ser814 }\end{array}$ & $\begin{array}{c}\text { Ile548, Lys593, Leu758, Asp761, } \\
\text { Cys813, Pro832, Arg836, Ile837, } \\
\text { Ala840 }\end{array}$ \\
\hline & 20 & -8.8 & Ile494, Asp684 & Lys500, Lys545, Arg569, Ser682 \\
\hline & 4 & -8.8 & Asn497, Arg569 & $\begin{array}{c}\text { Ile494, Lys500, Arg569, Lys577, } \\
\text { Ala685 }\end{array}$ \\
\hline & 21 & -8.7 & None & $\begin{array}{c}\text { Ile494, Lys500, Leu576, Lys577, } \\
\text { Ala685, Tyr689 }\end{array}$ \\
\hline & 1 & -8.6 & Asn497, Asp684 & Arg569, Ala580, Ala688, Tyr689 \\
\hline & 3 & -8.6 & Arg569, Gln573 & $\begin{array}{l}\text { Ile494, Lys500, Lys577, Ala580, } \\
\text { Ile589, Ala685, Ala688, Tyr689 }\end{array}$ \\
\hline & 5 & -8.6 & Arg569, GIn573 & Leu576, Lys577, Ala580, Ala685 \\
\hline \multirow[t]{10}{*}{ Helicase } & 14 & -9.2 & Glu341, Asp534 & Ala312, Ala313, Val340 \\
\hline & 13 & -9.2 & $\begin{array}{l}\text { Lys288, Ala316, } \\
\text { Arg443 }\end{array}$ & $\begin{array}{c}\text { Thr286, Ala316, Lys320, Gly538, } \\
\text { Ser539 }\end{array}$ \\
\hline & 15 & -9 & $\begin{array}{l}\text { Arg332, Glu319, } \\
\text { Cys342, Ser310, } \\
\text { Asp534 }\end{array}$ & Met378, Ala312, Ala316, Asp315 \\
\hline & 8 & -8.9 & $\begin{array}{l}\text { Gly285, Ala316, } \\
\text { Ser289, Lys288, } \\
\text { Glu375, GIn537 }\end{array}$ & Ala312, Lys320, GIn537 \\
\hline & 4 & -8.9 & Gly285, Lys288 & $\begin{array}{c}\text { Arg443, Arg442, Glu540, Lys320, } \\
\text { Ala316, Ala312, Ala313 }\end{array}$ \\
\hline & 19 & -8.7 & None & $\begin{array}{c}\text { Gly538, Glu319, Glu540, Ala316, } \\
\text { Ser535, Ala312, Ala313 }\end{array}$ \\
\hline & 1 & -8.6 & None & $\begin{array}{c}\text { Ala312, Cys342, Asp315, } \\
\text { Ala316,His311 }\end{array}$ \\
\hline & 22 & -8.6 & Asn459 & $\begin{array}{l}\text { Phe437, Lys460, Pro434, Gly433, } \\
\text { Lys430, Pro402, Tyr457, Ala403 }\end{array}$ \\
\hline & 23 & -8.5 & $\begin{array}{l}\text { Lys430, GIn281, } \\
\text { Val456, Tyr457 }\end{array}$ & Phe437, Pro434, Lys430, Leu455 \\
\hline & 24 & -8.4 & $\begin{array}{c}\text { Leu417, Asn557, } \\
\text { Asn516 }\end{array}$ & Phe422, Pro406, Pro408 \\
\hline
\end{tabular}


(A)

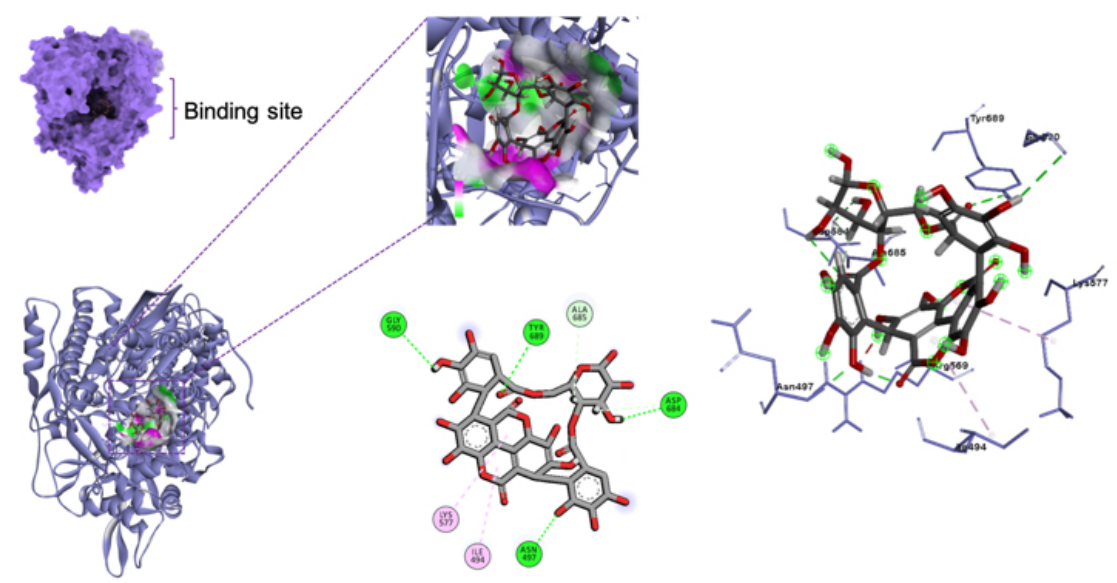

(B)
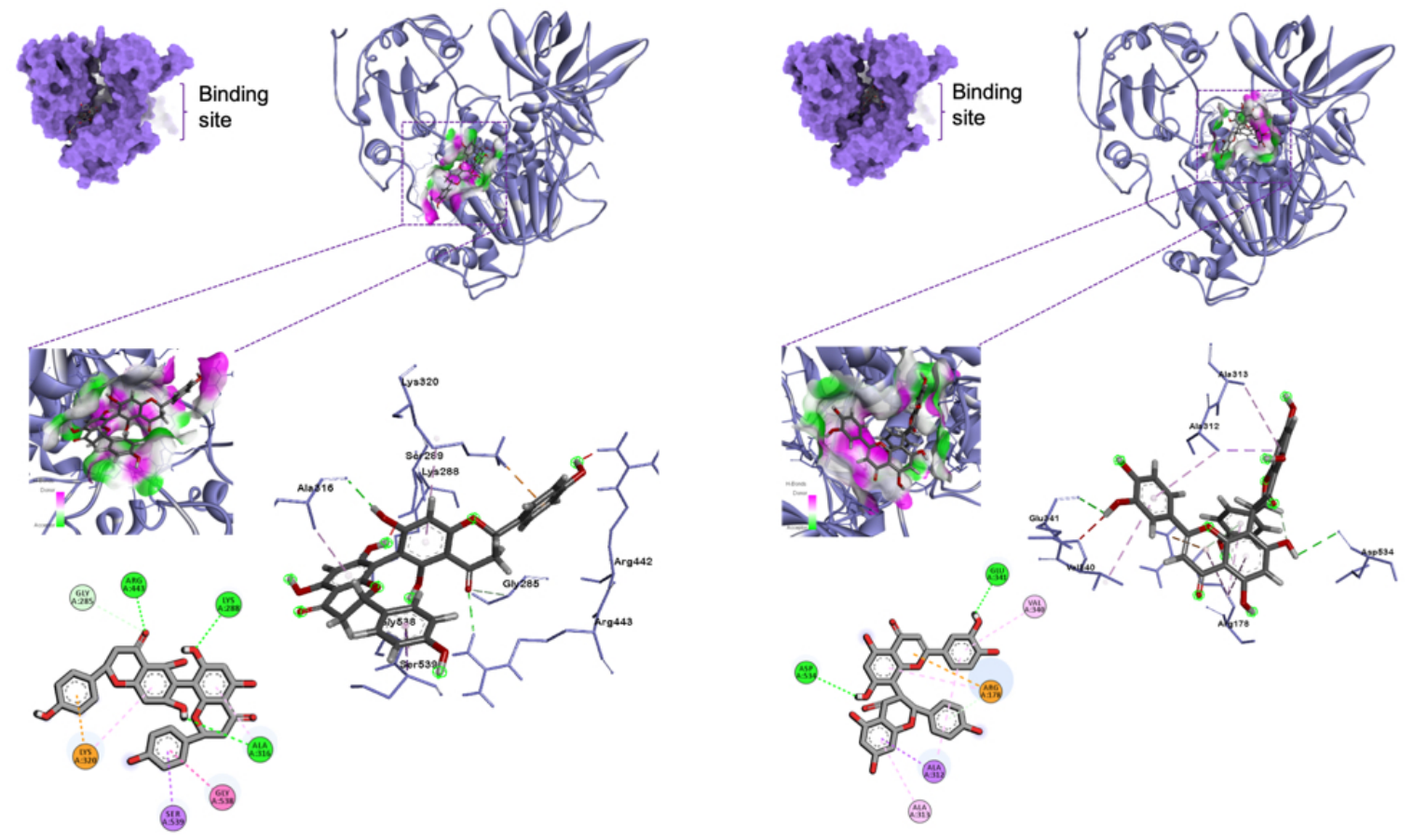

(i.:용

Figure 3 Top 1-binding compounds in complex with their target enzymes vital in replication: (A) punicalin (9) in complex with RdRp, (B) rhusflavanone (13) (left) and morelloflavone (14) (right) bound to helicase 
Compound 13 also occupied the Rec2A domain of the nucleotide binding site through a hydrogen bond of its pyrone (ring C) carbonyl with Arg443, an amide-pi stacked interaction of its hydroxyphenyl moiety (ring B') with Gly538, and a pi-sigma interaction of ring B' with Ser539. A pyrone (ring C) carbonyl further contributed to the binding affinity of compound 13 by binding to Thr286 through van der Waals forces. On the other hand, a dihydroxyphenyl moiety (ring B') of compound 14 bound Glu341 through hydrogen bonding and both Ala312 and Val340 by pi-alkyl interactions. Ring A of its chromanone functionality bound Ala313 through a pi-alkyl interaction and also Ala312 by pi-sigma interaction. These residues are members of the helicase Rec2A domain of the nucleotide binding site. In addition, a benzophyrone hydroxyl (ring A') of compound 14 bound Asp 534, which is a residue of the Rec1A helicase domain of the nucleotide binding site.

Molecular docking with enzymes functioning in the evasion of host immunity

SAM-dependent 2'-O-methyltransferase complex enzymes (nsp10/nsp16 complex)

Top compounds against nsp16 exhibited affinities from -9.3 to $-10.6 \mathrm{kcal} / \mathrm{mol}$. The SAMbinding site was targeted and the biflavonoid robustaflavone (4) and the alkaloid michellamine B (19) demonstrated the greatest affinity compared to the reference drug antrafenine with BE of $10.3 \mathrm{kcal} / \mathrm{mol}$ [32] (Table 3; Figure 4A). Hydroxyphenyl ring B of compound 4 exhibited pi-alkyl interactions with Leu6898 and Met6929, and a hydrogen bonding with Cys6913. The hydroxyphenyl ring B' showed carbon-hydrogen bonding with Asn6841. Moreover, its benzopyrone moiety (rings A and C) was in pi-anion interaction with Asp6897 and its chromene hydrogen was in hydrogen bonding with Asp6928. A van der Waals force interaction between its pyrone ring C oxygen and Gly6869 was also observed. 
Table 3 Binding affinities and interactions of top ten ligands against the nsps of the SAMdependent 2'-O-methyltransferase complex

\begin{tabular}{|c|c|c|c|c|}
\hline Target & Cpd & $\begin{array}{l}\text { Binding } \\
\text { affinity }\end{array}$ & Hydrogen bonds & Other interactions \\
\hline \multirow[t]{10}{*}{ nsp16 } & 19 & -10.6 & Asp6897, Asp6928 & $\begin{array}{c}\text { Cys6913, Cys6914, Met6929, Asp6931 } \\
\text { Phe6947, Gly6869, Leu6898 }\end{array}$ \\
\hline & 4 & -10.6 & $\begin{array}{c}\text { Lys6844, Cys6913, Asp6928, } \\
\text { Asp6928, Asn6996 }\end{array}$ & $\begin{array}{c}\text { Asn6841, Asp6897, Gly6869, Met6929, } \\
\text { Leu6898, Glu7001 }\end{array}$ \\
\hline & 1 & -10.2 & $\begin{array}{c}\text { Asn6841, Asp6897, Leu6898, } \\
\text { Asp6912 }\end{array}$ & $\begin{array}{c}\text { Pro6932, Asp6897, Leu6898, Met6929, } \\
\text { Phe6947 }\end{array}$ \\
\hline & 23 & -10.2 & Asp6931, Cys6913, Tyr6930 & $\begin{array}{c}\text { Asp6931, Phe6947, Asp6912, } \\
\text { Leu6898, Met6929, Asp6897, Gly6869, } \\
\text { Asp6928 }\end{array}$ \\
\hline & 25 & -9.5 & $\begin{array}{c}\text { Gly6911, Asp6873, Gly6871, } \\
\text { Tyr6930 }\end{array}$ & Leu6898, Cys6913, Met6929, Tyr6930, \\
\hline & 3 & -9.5 & Asn6841, Lys6844, Asn6996 & $\begin{array}{c}\text { Met6839, Met6840, Tyr6930, Pro6932, } \\
\text { Ser6999 }\end{array}$ \\
\hline & 18 & -9.5 & $\begin{array}{c}\text { Asn6841, Asp6897, Asn6899, } \\
\text { Tyr6930, Asn6996, Ser6999, } \\
\text { Glu7001 }\end{array}$ & Lys6844, Lys6968 \\
\hline & 13 & -9.5 & Ser759, Asp761 & Leu758, Ala688, Asp760, Cys813 \\
\hline & 26 & -9.4 & $\begin{array}{c}\text { Asn6899, Asp6873, Lys6844, } \\
\text { Asn6841, Asp6928, Leu6898, } \\
\text { Asp6912 }\end{array}$ & $\begin{array}{c}\text { Cys6913, Phe6947, Gly6869, Tyr6930, } \\
\text { Asp6897, }\end{array}$ \\
\hline & 20 & -9.3 & Lys6844, Gly6869, Asp6873 & Lys6935 \\
\hline \multirow[t]{13}{*}{ nsp10 } & 4 & -7.7 & Asp4335 & Arg4331, Ile4334, Lys4346 \\
\hline & 1 & -7.4 & His4333, Ile4334 & Arg4331 \\
\hline & 27 & -7.3 & Asp4344, Leu4345 & $\begin{array}{c}\text { Tyr4329, Cys4327, His4336, Pro4337, } \\
\text { Leu4345, Leu4365 }\end{array}$ \\
\hline & 15 & -7.3 & $\begin{array}{c}\text { Arg4331, His4333, Lys4348, } \\
\text { Gly4323, Tyr4349 }\end{array}$ & Val4295, Gly4322, Ala4324 \\
\hline & 19 & -7.2 & Lys 4346 & $\begin{array}{c}\text { Cys4330, His4333, Ala4324, Lys4346, } \\
\text { Val4295 }\end{array}$ \\
\hline & 11 & -7.2 & Asn4293 & Cys4294, Lys4296, Val4295, Leu4298 \\
\hline & 23 & -7.1 & $\begin{array}{l}\text { Cys4330, His4333, Ile4334, } \\
\text { Asp4335, His4336 }\end{array}$ & Lys4346 \\
\hline & 25 & -7 & $\begin{array}{l}\text { Tyr4329, His4333, Ala4324, } \\
\text { Leu4345, Lys4348 }\end{array}$ & Lys4346, Tyr4349 \\
\hline & 8 & -7 & Cys4343 & Lys4346, Gly4347, Phe4342 \\
\hline & 26 & -6.9 & $\begin{array}{c}\text { Leu4345, Lys4348, Gly4347, } \\
\text { Ala4324, His4333, lle4334, } \\
\text { Tyr4329 }\end{array}$ & Lys4348, Arg4331, Lys4346, \\
\hline & 17 & -6.9 & Tyr4329, His4336 & $\begin{array}{c}\text { Asn4293, Arg4331, Ala4324, His4333, } \\
\text { Lys4346, Ile4334 }\end{array}$ \\
\hline & 9 & -6.9 & $\begin{array}{l}\text { Ala4324, Lys4346, Lys4348, } \\
\text { Tyr4349 }\end{array}$ & $\begin{array}{c}\text { Val4295, Gly4322, Gly4347, Ala4324, } \\
\text { Tyr4349 }\end{array}$ \\
\hline & 20 & -6.9 & Leu4345, Gly4347, Lys4348 & Ala4324, Arg4331, His4333 \\
\hline
\end{tabular}


(A)
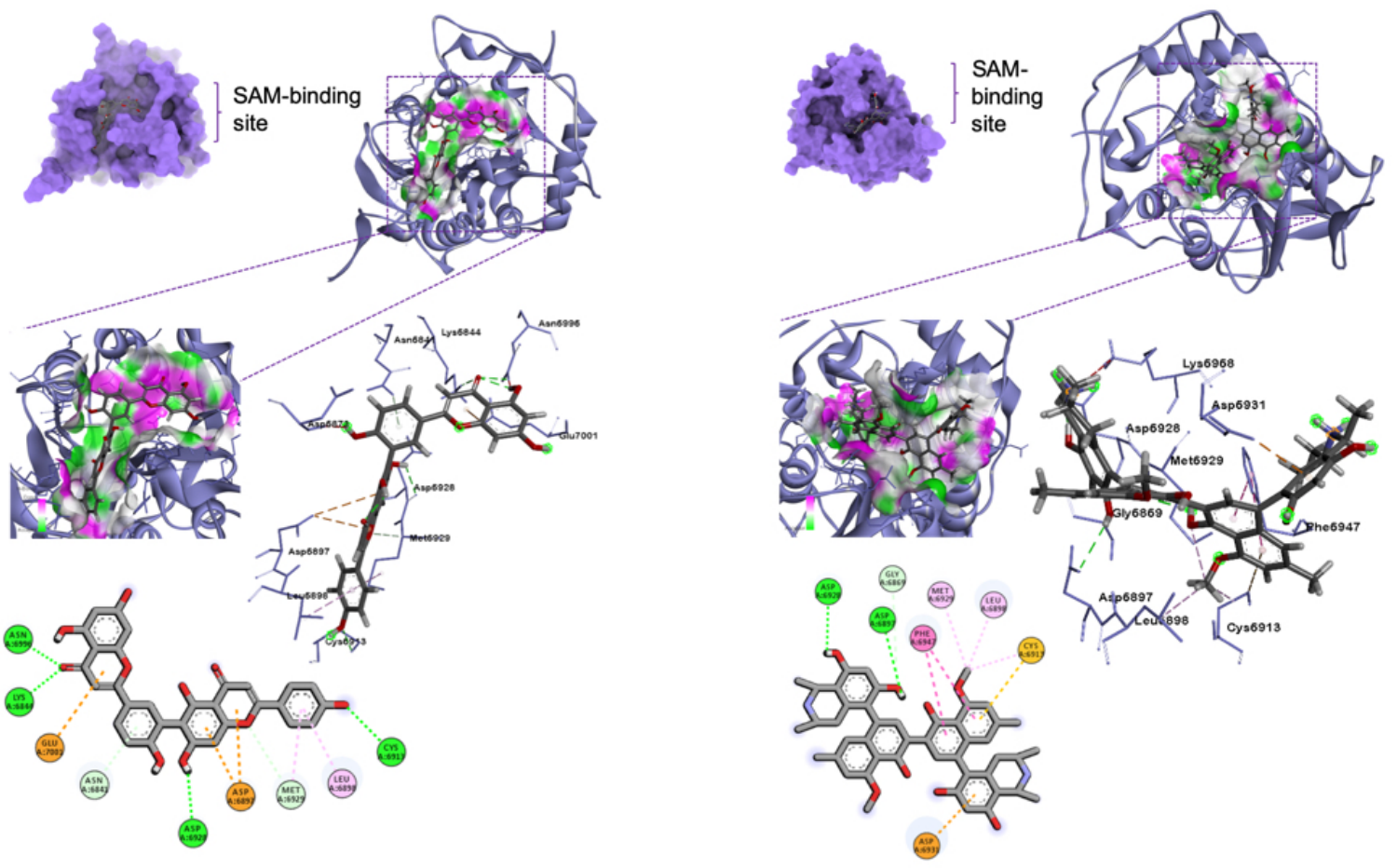

(B)

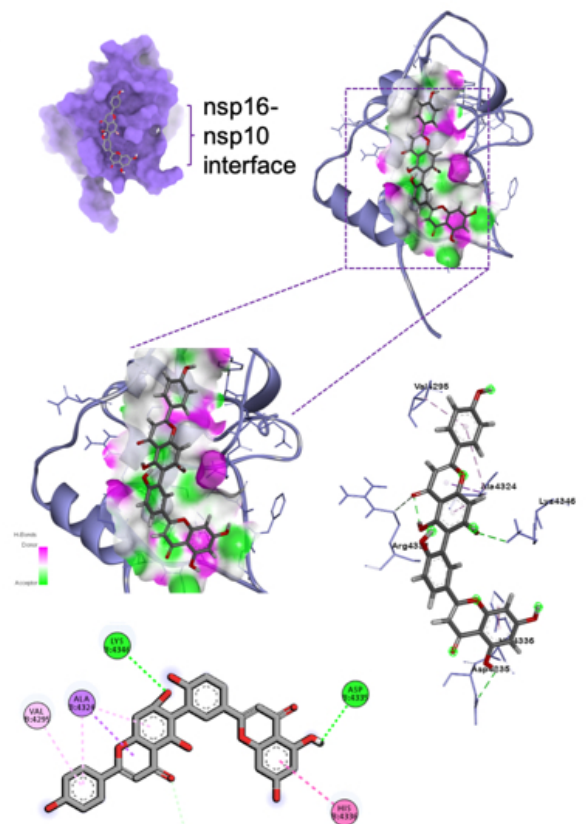

(C)

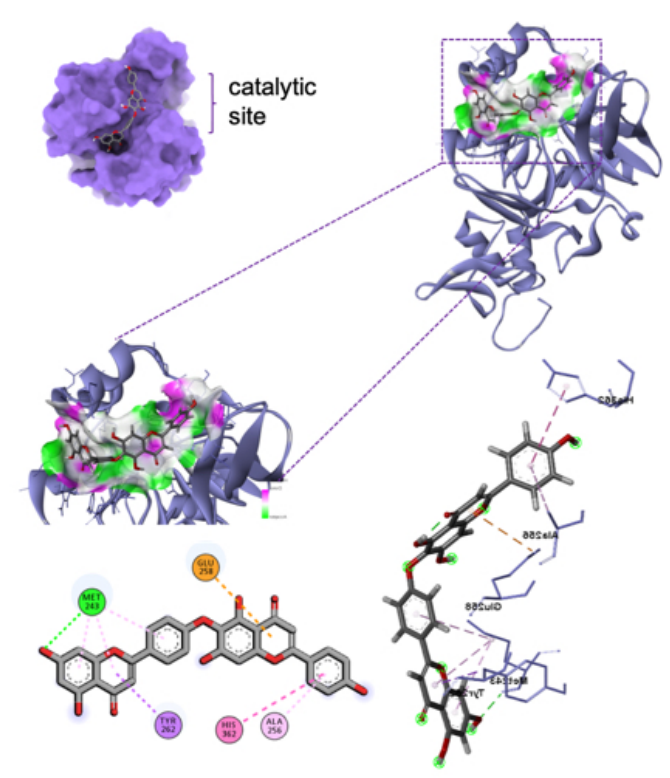

Figure 4 Top 1-binding compounds in complex with nsps involved in host immunity evasion: (A) robustaflavone (4) (left) and michellamine B (19) (right) complexed with S-adenosylmethioninedependent 2'-O-methyltransferase, (B) robustaflavone (4) bound to nsp10, and (C) hinokiflavone (15) bound to nsp15 
Another pyrone moiety (ring C') also interacted with nsp16 through a pi-anion interaction with Glu7001. Lys6844 and Asn6996 were occupied by the pyrone ring C' carbonyl through hydrogen bonding. On the other hand, compound 19's isoquinoline moiety was in H-bonding with Asp6928 and Asp6897 and in carbon-hydrogen bonding with Gly6869. Another isoquinoline moiety was in pi-anion interaction with Asp6931. Moreover, a naphthalene moiety participated in pi-pi T-shaped interaction with Phe6947 and in pi-sulfur interaction with Cys6914. A methyl group connected to naphthalene manifested alkyl interactions with Met6929, Leu6898, and Cys6913.

In connection, top compounds against nsp10 showed binding affinities of -6.9 to -7.7 $\mathrm{kcal} / \mathrm{mol}$ comparable to the $-8.5 \mathrm{kcal} / \mathrm{mol} \mathrm{BE}$ of siramesine [32]. The interface between $\mathrm{nsp} 10$ and nsp16 was targeted and several interactions were observed. Biflavonoid robustaflavone (4) had the highest affinity (Figure 4B). Its pyrone ring C' was in carbon-hydrogen bonding with lle4334. Chromanone (ring A') hydroxyl formed H-bonding with Asp4335. Carbon atoms of chromanone (rings A and C) and hydroxyphenyl ring B' formed salt bridges with Lys4346 while ring C' carbonyl exhibited a salt bridge with Arg4331.

Endoribonuclease (nsp15)

Top-scoring compounds against nsp15 exhibited affinities of -8.6 to $-7.3 \mathrm{kcal} / \mathrm{mol}$, compared to that of the reference nitrogenous inhibitor, Z16215674, with $-9.07 \mathrm{kcal} / \mathrm{mol}$ [33] (Table 4). The biflavonone hinokiflavone (15) scored the highest affinity, noting its interactions with its putative binding site that is proximal to the catalytic triad of His235, His250, and Lys290: flavone moiety (rings A, B, and C) in hydrogen bonding and pi-alkyl interaction with Met243, pyrone ring $\mathrm{C}$ in pi-sigma interaction with Tyr262, pyrone ring $C^{\prime}$ in pi-anion interaction with Glu258, and hydroxyphenyl ring B' in pi-alkyl and pi-pi stacked interactions with Ala256 and His362, respectively (Figure 4C). 
Table 4 Binding affinities and interactions of top ten ligands against nsp15

\begin{tabular}{|c|c|c|c|c|}
\hline Target & Cpd & $\begin{array}{l}\text { Binding } \\
\text { affinity }\end{array}$ & Hydrogen bonds & Other interactions \\
\hline \multirow[t]{10}{*}{ nsp15 } & 15 & -8.6 & Met243 & $\begin{array}{c}\text { Met243, Tyr262, Glu258, } \\
\text { His362, Ala256 }\end{array}$ \\
\hline & 4 & -8.5 & None & $\begin{array}{c}\text { Lys281, Glu285, Tyr262, } \\
\text { Met243 }\end{array}$ \\
\hline & 1 & -8.4 & Gly254 & Met243, Ala256, Glu258 \\
\hline & 25 & -8.1 & Phe265, Ser266 & Lys281, Ser266, Ala256 \\
\hline & 23 & -8 & None & $\begin{array}{c}\text { Glu258, Ala256, Gly263, } \\
\text { Asp264, Phe265 }\end{array}$ \\
\hline & 26 & -7.8 & Glu285, Glu364 & $\begin{array}{c}\text { Ala256, Ser266, Met243, } \\
\text { Lys281, Glu285 }\end{array}$ \\
\hline & 12 & -7.7 & Glu285 & $\begin{array}{c}\text { Ala256, Met243, Tyr262, } \\
\text { Lys281 }\end{array}$ \\
\hline & 14 & -7.7 & Arg282 & Glu285, Lys281, Phe265 \\
\hline & 13 & -7.3 & Gly263, Asp264 & $\begin{array}{c}\text { Ala256, His259, Asp264, } \\
\text { Met243, Glu285 }\end{array}$ \\
\hline & 17 & -7.3 & Glu258 & None \\
\hline
\end{tabular}

Druggability, ADME, and Toxicity

Six of the 20 top-scoring and multi-targeting repurposed phytochemicals were found to be druggable according to Lipinski's rule of five (Table 5). Hinokiflavone (15) is a top-scoring, multitargeting, druggable compound. Moreover, compounds 5 and 17 were multi-targeting and exhibited good gastrointestinal absorption property.

In addition, compounds $\mathbf{2 5}$ and $\mathbf{2 6}$ showed the best solubility in water of -2.85 , thereby depicting good excretion properties (Table 6). Toxicity prediction through OSIRIS Property Explorer showed that all top compounds except 11, 14, 15, 18, 19, and 20 have no mutagenic, tumorigenic, irritant, and reproductive toxicity risks (Table 6). 
Table 5 Druggability of top, multi-targeting compounds according to Lipinski's rule of five

\begin{tabular}{|c|c|c|c|c|c|c|c|}
\hline Cpd & $\begin{array}{l}\mathrm{MW} \\
<500\end{array}$ & $\begin{array}{c}\text { \#H-bond } \\
\text { acceptors } \\
<10\end{array}$ & $\begin{array}{l}\text { \#H-bond } \\
\text { donors } \\
<5\end{array}$ & $\begin{array}{l}\text { Lipophilicity } \\
\text { MLogP }<5\end{array}$ & $\begin{array}{l}\text { Lipinski } \\
\text { violations }\end{array}$ & $\begin{array}{l}\text { Drug- } \\
\text { likeness }\end{array}$ & Target \\
\hline 1 & 538.46 & 10 & 6 & 0.25 & 2 & No & $\begin{array}{c}\text { PLpro, 3CLpro, } \\
\text { RdRp, helicase, } \\
\text { nsp10, nsp16, } \\
\text { nsp15 }\end{array}$ \\
\hline 2 & 426.72 & 1 & 0 & 6.92 & 1 & Yes & PLpro, RdRp \\
\hline 3 & 570.8 & 4 & 0 & 5.03 & 2 & No & $\begin{array}{l}\text { PLpro, 3CLpro, } \\
\text { RdRp, nsp16 }\end{array}$ \\
\hline 4 & 538.46 & 10 & 6 & 0.25 & 2 & No & $\begin{array}{c}\text { PLpro, 3CLpro, } \\
\text { RdRp, helicase, } \\
\text { nsp10, nsp16, } \\
\text { nsp15 }\end{array}$ \\
\hline 5 & 472.7 & 4 & 3 & 4.97 & 1 & Yes & PLpro, RdRp \\
\hline 8 & 538.46 & 10 & 6 & 0.25 & 2 & No & $\begin{array}{l}\text { PLpro, 3CLpro, } \\
\text { helicase, nsp10 }\end{array}$ \\
\hline 9 & 782.53 & 22 & 13 & -2.56 & 3 & No & $\begin{array}{l}\text { PLpro, RdRp, } \\
\text { nsp10 }\end{array}$ \\
\hline 10 & 456.7 & 3 & 2 & 5.82 & 1 & Yes & PLpro, RdRp \\
\hline 11 & 540.47 & 10 & 3 & 0.41 & 2 & No & 3CLpro, nsp10 \\
\hline 12 & 498.74 & 4 & 1 & 5.97 & 1 & Yes & 3CLpro, nsp15 \\
\hline 13 & 542.49 & 10 & 6 & 0.58 & 2 & No & $\begin{array}{c}\text { 3CLpro, helicase, } \\
\text { nsp16, nsp15 }\end{array}$ \\
\hline 14 & 556.47 & 11 & 7 & -0.08 & 3 & No & $\begin{array}{c}\text { 3CLpro, helicase } \\
\text { nsp15 }\end{array}$ \\
\hline 15 & 538.46 & 10 & 5 & 0.52 & 1 & Yes & $\begin{array}{c}\text { 3CLpro, RdRp, } \\
\text { helicase, nsp10, } \\
\text { nsp15 }\end{array}$ \\
\hline 17 & 520.65 & 8 & 4 & 1.95 & 1 & Yes & $\begin{array}{l}\text { 3CLpro, nsp10, } \\
\text { nsp15 }\end{array}$ \\
\hline 18 & 992.64 & 28 & 14 & -3.39 & 3 & No & RdRp, np16 \\
\hline 19 & 756.88 & 10 & 8 & 3.18 & 2 & No & $\begin{array}{l}\text { RdRp, helicase, } \\
\text { nsp10, nsp16 }\end{array}$ \\
\hline 20 & 1008.75 & 28 & 14 & -3.39 & 3 & No & $\begin{array}{l}\text { RdRp, nsp10, } \\
\text { nsp16 }\end{array}$ \\
\hline 23 & 578.52 & 14 & 8 & -2.96 & 3 & No & $\begin{array}{l}\text { helicase, nsp10, } \\
\text { nsp16, nsp15 }\end{array}$ \\
\hline 25 & 516.45 & 12 & 7 & -0.35 & 3 & No & $\begin{array}{l}\text { nsp10, nsp16, } \\
\text { nsp15 }\end{array}$ \\
\hline 26 & 516.45 & 12 & 7 & -0.35 & 3 & No & $\begin{array}{c}\text { nsp10, nsp16, } \\
\text { nsp15 }\end{array}$ \\
\hline
\end{tabular}


Table 6 Toxicity risks of top, multi-targeting compounds as predicted by OSIRIS Property Explorer

\begin{tabular}{|c|c|c|c|c|c|}
\hline \multirow{2}{*}{ Cpd } & \multicolumn{4}{|c|}{ Toxicity Risk } & \multirow{2}{*}{$\begin{array}{c}\text { Solubility } \\
\text { (LogS) }\end{array}$} \\
\hline & Mutagenic & Tumorigenic & Irritant & $\begin{array}{c}\text { Reproductive } \\
\text { effective }\end{array}$ & \\
\hline 1 & No & No & No & No & -6.16 \\
\hline 2 & No & No & No & No & -6.97 \\
\hline 3 & No & No & No & No & -7.66 \\
\hline 4 & No & No & No & No & -6.18 \\
\hline 5 & No & No & No & No & -5.66 \\
\hline 8 & No & No & No & No & -6.18 \\
\hline 9 & No & No & No & No & -5.89 \\
\hline 10 & No & No & No & No & -6.11 \\
\hline 11 & No & No & No & High Risk & -5.11 \\
\hline 12 & No & No & No & No & -6.37 \\
\hline 13 & No & No & No & No & -5.75 \\
\hline 14 & No & No & No & High Risk & -4.82 \\
\hline 15 & No & No & No & High Risk & -6.69 \\
\hline 17 & No & No & No & No & -4.42 \\
\hline 18 & No & No & $\begin{array}{l}\text { High } \\
\text { Risk }\end{array}$ & No & -3.54 \\
\hline 19 & No & High Risk & No & No & -11.38 \\
\hline 20 & No & No & $\begin{array}{l}\text { High } \\
\text { Risk }\end{array}$ & No & -3.54 \\
\hline 23 & No & No & No & No & -2.95 \\
\hline 25 & No & No & No & No & -2.85 \\
\hline 26 & No & No & No & No & -2.85 \\
\hline
\end{tabular}


Discussion:

The exploration of the SARS-CoV-2 genome revealed viral enzymes that can be targeted to combat COVID-19. Aside from the structural proteins including the spike and envelope proteins, SARS-CoV-2 pathogenesis requires non-structural proteins that can be targeted due to their functions in post-translational processing, replication, and host immunity evasion [34]. The targeted nsps were PLpro, 3CLpro, RdRp, helicase, SAM-dependent 2'-O-methyltransferase and its cofactor (nsp10), and the endoribonuclease. The understanding of these nsps requires knowing the fate of the SARS-CoV-2 genome after it is released into the host cell. The open reading frames $1 \mathrm{a}$ and $1 \mathrm{ab}$ genes at the 5 '-end of the genome are translated into polyproteins pp1a and pp1ab, which contain nsps 1-10 and nsps 1-16, respectively [35]. PLpro and 3CLpro are mainly involved in post-translational processing through the autolytic cleavage of the polyproteins wherein PLpro cleaves 3 sites at the N-terminus while 3CLpro cleaves through the remaining sites (11 sites in pp1ab) to release the nsps [34] (Figure 5).

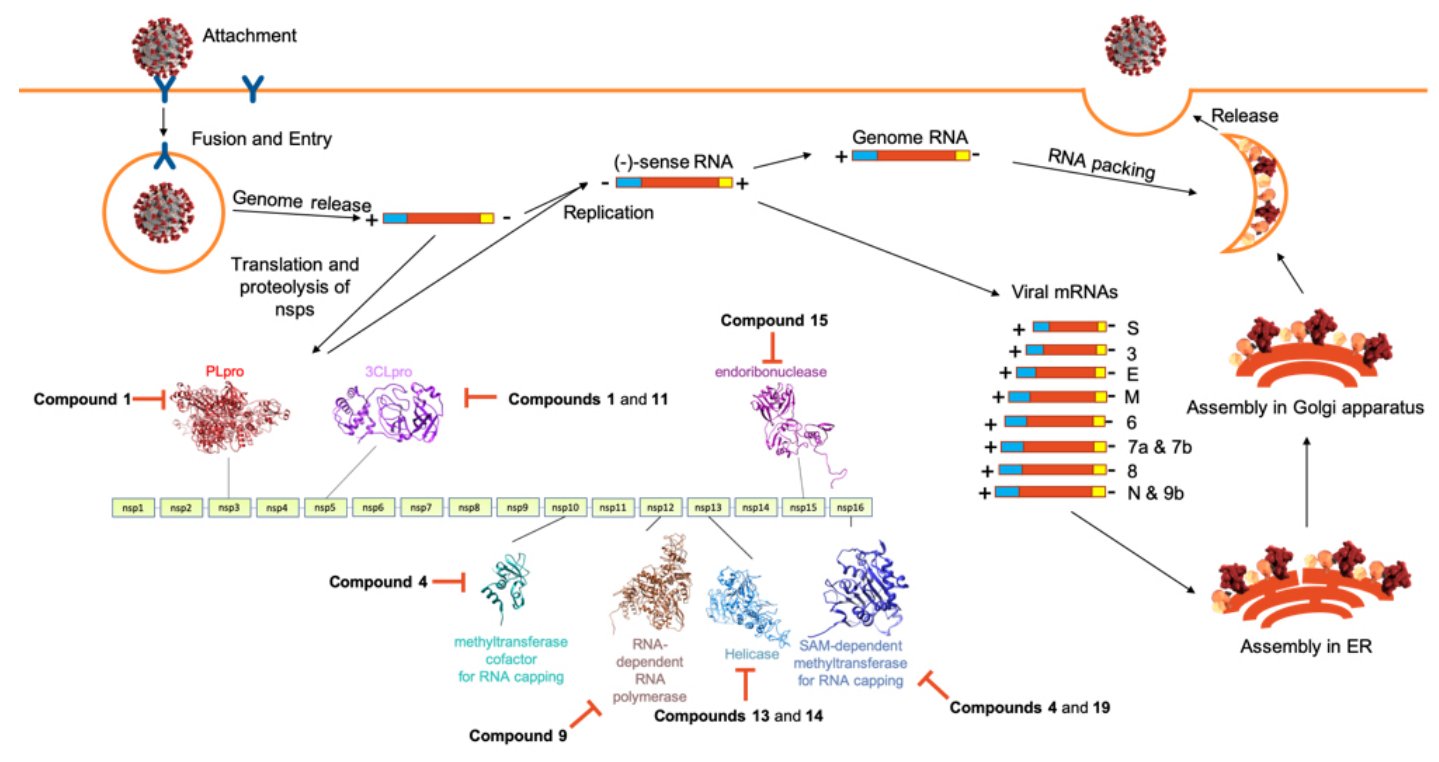

Figure 5 The SARS-CoV-2 life cycle highlighting the role of nsps in replication and transcription and the potential inhibited target SARS-CoV-2 nsps of repurposed anti-HIV RT phytochemicals. SARS-CoV-2 virion image credit: CDC/ Alissa Eckert (MSMI) and Dan Higgins (MAMS) 
These cysteine proteases were included in this study, although these are widely established targets [36, 37], in order to provide a full picture of the infective mechanisms provided by nsps from autolytic processing to replication-transcription and genome modifications in SARSCoV-2. Their inclusion also highlights the multi-targeting capacity of the tested compounds against the nsps. Proceeding to replication-transcription, the replication-transcription complex which is notably composed of RdRp and helicase replicates the positive-sense genome into a negative-sense RNA genome that serves as the template for the subsequent replication of the new positive-sense genome and the transcription of viral subgenomic mRNAs that are further translated into structural and accessory proteins [38]. In this complex, RdRp elongates the daughter strand through the polymerization of nucleotides, while helicase clears RNA secondary structures and RNA-binding proteins [39]. In addition, among those targeted nsps in this study, the complex of SAM-dependent C2'-O-methyltransferase (nsp16)-that is specific to methylguanine-triphosphate-adenosine-and nsp 10 as its cofactor confer host immune evasion properties for SARS-CoV-2 due to the cap methylation of viral mRNAs [40]. Similarly, the endoribonuclease (nsp15) cleaves at the 3 ' end of uridylates[41] and also antagonizes the activation of host dsRNA sensors [42], thereby eluding host immunity. Our results, therefore, highlighted the role of anti-HIV RT phytochemicals as potential antagonists of SARS-CoV-2 by interfering with the functionality of these nsps.

With known targets in the SARS-CoV-2 pathogenesis, discovery of therapeutic agents is possible amidst the unavailability of laboratory-based high throughput screening experiments. This endeavor is accelerated by computer-aided drug discovery through virtual screening which offers a structural approach that focuses on key residues vital in the functioning of the target enzyme [43]. Thus, this removes the trial-and-error, random screening and provides primary direction through lead compounds for drug development [16]. In connection with this efficiency, the repurposing of established anti-HIV compounds led to the discovery of new anti-SARS-CoV- 
2 compounds. The repurposing of anti-HIV RT phytochemicals against SARS-CoV-2 is an opportunistic approach on the basis that both SARS-CoV-2 and HIV are positive-sense RNA viruses that rely on RNA-dependent polymerases-SARS-CoV-2 RdRp and HIV reverse transcriptase-for their incorporation into the host cell machinery and encode polyproteinsreplicase polyprotein 1a and 1ab for SARS-CoV-2 and Gag and Gag-Pol polyproteins for HIVthat contain functional enzymes and structures vital for their development to a mature virion. Enzymes in the HIV Gag-Pol polyprotein include the viral protease that cleaves the polyproteins and reverse transcriptase that reversely transcribes the RNA genome into DNA for host cell integration [44]. As previously discussed, this is similar to SARS-CoV-2 polyproteins that contain the nsps.

The repurposing of established anti-HIV compounds means that the lead compounds in this study can be easily obtained from previously explored plants. This is in consideration of the fact that despite the successful formulation and clinical trials of vaccines, not all countries can swiftly procure and distribute vaccines to their population [45]. Vaccine percent efficacies imply that populations can still be infected, thereby highlighting the need for continuous anti-COVID-19 drug development. Since some of these plant sources are consumed by populations, the top 1 multi-targeting compounds may be taken in by people around the world. Amentoflavone (1) can be obtained from the Chinese olive fruit, Canarium album [46]. Robustaflavone (4) can be obtained from the leaves of Garcinia epunctata, which is used in Cameroon folk medicine [47]. Punicalin (9) can be obtained from the peel of pomegranate, Punica granatum [48]. Volkensiflavone (11) and morelloflavone (14) can be obtained from the seeds and rinds of Garcinia intermedia [49]. Rhusflavanone (13) can be obtained from the fruit of Searsia parviflora [50]. Hinokiflavone (15) can be obtained from Selaginella tamariscina [51]. Lastly, michellamine B (19) can be obtained from the leaves of Ancistrocladus korupensis [52]. The multi-targeting potential of compounds increases the chance of getting a maximal inhibitory effect [53]. Although 
most of these top 1 compounds were predicted in silico to be non-druggable, efforts are rising to explore compounds in the oral druggable space beyond the rule of five (bRo5) $[54,55]$ and these can still serve as templates for drug design or even undergo in vitro assays for validating their anti-SARS-CoV-2 properties. Additionally, four of these did not manifest toxicity in silico. The biflavonoids volkensiflavone (11), morelloflavone (14), and hinokiflavone (15) were computationally predicted as non-mutagenic, non-tumorigenic and non-irritant, but were predicted to pose reproductive toxicity risk which may be attributed to their chromene and hydroxyphenyl moieties. It should be noted, however, that hinokiflavone (15) is the only druggable top 1 compound. Michellamine B (19) was also predicted to be tumorigenic due to its naphthalene moiety. Nevertheless, these can still serve as drug templates considering the consumption of their plant sources among populations and their inhibitory interactions with their target nsps. In addition, compounds 5 and 17 exhibited good gastrointestinal absorptive feature as implicated by their favorable lipophilicity and polar surface area [56]. Moreover, these did not manifest any form of toxicity in silico.

Conclusions:

The search for anti-COVID-19 therapeutic agents is a response to the continuous spread of the virus amidst vaccine availability. The similarity between the pathogenesis of HIV and SARSCoV-2 inspired the repurposing of previously reported anti-HIV reverse transcriptase phytochemicals against SARS-CoV-2 nsps implicated in viral replication, post-translational processing and host immunity evasion mechanisms. The top-ranking polyphenolics, terpenoids and alkaloid identified in this study can be further screened using confirmatory in vitro and in vivo assays, and can serve as prototypes for designing novel anti-COVID-19 drugs. As promising drug templates, functionalities in the compound structure can be modified to improve druggability and pharmacokinetic properties. 
List of Abbreviations:

3CLpro: 3-chymotrypsin-like protease; ADME: Absorption, digestion, metabolism, and excretion; BE: Binding energy; COVID-19: Coronavirus disease 2019; Cpd: compound; dsDNA: doublestranded DNA; HIV: Human immunodeficiency virus; kcal/mol: Kilocalorie/mole; nsp: Nonstructural protein; PDB: Protein data bank; PLpro: Papain-like protease; RdRp: RNA-dependent RNA polymerase; RNA: Ribonucleic acid; RT: Reverse transcriptase; SARS-CoV-2: Severe acute respiratory syndrome coronavirus 2 
References

[1] Albano PM, Notarte KI, Macaranas I, Maralit B (2020) Cross-contamination in molecular diagnostic laboratories in low-and middle-income countries. Philipp J Pathol 5: 7-11. doi:10.21141/PJP.2020.09

[2] Viswanathan T, Arya S, Chan SH, Qi S, Dai N, Hromas RA, Park JG, Oladunni F, MartinezSobrido L, Gupta YK (2020) Structural Basis of RNA Cap Modification by SARS-CoV-2 Coronavirus. Nat Commun 11: 3718. doi:10.1038/s41467-020-17496-8

[3] World Health Organization. WHO Coronavirus Disease (COVID-19) dashboard. https://covid19.who.int/. Accessed 19 February 2021.

[4] Richman D (2020) Antiviral drug discovery to address the COVID-19 pandemic. mBio 11. doi:10.1128/mBio.02134-20

[5] Shahzad F, Anderson D, Najafzadeh M (2020) The antiviral, anti-inflammatory effects of natural medicinal herbs and mushrooms and SARS-CoV-2 infection. Nutrients 12: 2573. doi:10.3390/nu12092573

[6] Davies JP, Almasy KM, McDonald EF, Plate L (2020) Comparative multiplexed interactomics of SARS-CoV-2 and homologous coronavirus non-structural proteins identifies unique and shared host-cell dependencies. bioRxiv. doi:10.1101\%2F2020.07.13.201517

[7] Astuti I, Ysrafil (2020) Severe acute respiratory syndrome coronavirus 2 (SARS-CoV-2): An overview of viral structure and host response. Diabetes Metab Syndr 14: 407-412. doi:10.1016\%2Fj.dsx.2020.04.020 
[8] Gil C, Ginex T, Maestro I, Nozal V, Barrado-Gil L, Cuesta-Geijo MÁ. et al. (2020) COVID-19: Drug targets and potential treatments. J Med Chem 63:12359-12386. doi:10.1021/acs.jmedchem.0c00606

[9] Forrestall K, Burley D, Cash M, Pottie I, \& Darvesh S (2020) 2-Pyridone natural products as inhibitors of SARS-CoV-2 main protease. Chem Biol Interact 109348. doi:10.1016/j.cbi.2020.109348

[10] Notarte KI, Devanadera MK, Mayor AB, Cada MC, Pecundo MH, Macabeo AP (2019) Toxicity, antibacterial, and antioxidant activities of fungal endophytes Colletotrichum and Nigrospora spp. isolated from Uvaria grandiflora. Philipp J Sci 148: 503-510.

[11] Quimque MTJ, Notarte KIR, Letada A, Fernandez RAT, Pueblos KRS, Pilapil DYH et al. (2020) Antiproliferative, cholinesterase and phosphodiesterase inhibitory activity of the DCM sub-extract of Uvaria alba: In vitro and in silico perspectives [pre-print]. ChemRxiv. doi:10.26434/chemrxiv.12924980.v2

[12] Elzupir AO (2020) Inhibition of SARS-CoV-2 main protease 3CLpro by means of $\alpha-$ ketoamide and pyridone-containing pharmaceuticals using in silico molecular docking. J Mol Struct 128878. doi:10.1016/j.molstruc.2020.128878

[13] Fakhar Z, Faramarzi B, Pacifico S, Faramarzi S (2020) Anthocyanin derivatives as potent inhibitors of SARS-CoV-2 main protease: An in-silico perspective of therapeutic targets against COVID-19 pandemic. J Biomol Struct Dyn: 1-13. doi:10.1080/07391102.2020.1801510 [14] Gentile D, Patamia V, Scala A, Sciortino MT, Piperno A, Rescifina A (2020) Putative inhibitors of SARS-CoV-2 main protease from a library of marine natural products: A virtual screening and molecular modeling study. Mar drugs 18: 225. doi:10.3390/md18040225 
[15] Khan A, Khan M, Saleem S, Babar Z, Ali A, Khan AA. et al. (2020) Phylogenetic analysis and structural perspectives of RNA-Dependent RNA-Polymerase inhibition from SARS-CoV-2 with natural products. Interdiscip Sci 12: 335-348. doi:10.1007/s12539-020-00381-9

[16] Quimque MTJ, Notarte KIR, Fernandez RAT, Mendoza MAO, Liman RAD. et al. (2020) Virtual screening-driven drug discovery of SARS-CoV2 enzyme inhibitors targeting viral attachment, replication, post-translational modification and host immunity evasion infection mechanisms. J Biomol Struct Dyn 16: 1-18. doi:10.1080/07391102.2020.1776639

[17] Zahran EM, Albohy A, Khalil A, Ibrahim AH, Ahmed HA, El-Hossary EM. et al. (2020) Bioactivity potential of marine natural products from Scleractinia-associated microbes and in silico anti-SARS-COV-2 evaluation. Mar Drugs 18: 645. doi:10.3390/md18120645

[18] Pettersen EF, Goddard TD, Huang CC, Couch GS, Greenblatt DM, Meng EC. et al., (2004) UCSF Chimera-A visualization system for exploratory research and analysis. J Comput Chem 25: 1605-1612. doi:10.1002/jcc.20084

[19] Yoshimoto FK (2020) The proteins of Severe Acute Respiratory Syndrome Coronavirus-2 (SARS CoV-2 or n-COV19), the cause of COVID-19. Protein J 39: 198-216. doi: $10.1007 / s 10930-020-09901-4$

[20] Gorbalenya AE, Koonin EV, Donchenko AP, Blinov VM (1989) Coronavirus genome: Prediction of putative functional domains in the non-structural polyprotein by comparative amino acid sequence analysis. Nucleic Acids Res 17: 4847-4861. doi:10.1093/nar/17.12.4847

[21] Seybert A, Hegyi A, Siddell SG, Ziebuhr J (2000) The human coronavirus 229E superfamily 1 helicase has RNA and DNA duplex-unwinding activities with 5'-to-3' polarity. RNA 6: 10561068. doi:10.1017/s1355838200000728 
[22] van Dinten LC, van Tol H, Gorbalenya AE, Snijder EJ (2000) The predicted metal-binding region of the arterivirus helicase protein is involved in subgenomic mRNA synthesis, genome replication, and virion biogenesis. J Virol 74: 5213-5223. doi:10.1128/jvi.74.11.5213-5223.2000

[23] Chinsembu KC (2019) Chemical diversity and activity profiles of HIV-1 reverse transcriptase inhibitors from plants. Rev Bras Farmacogn 29: 504-528. doi:10.1016/j.bjp.2018.10.006

[24] Hanwell MD, Curtis DE, Lonie DC, Vandermeersch T, Zurek E, Hutchison GR (2012) Avogadro: An advanced semantic chemical editor, visualization, and analysis platform. J Cheminformatics 4: 17. doi:10.1186/1758-2946-4-17

[25] Wang J, Wang W, Kollman PA, Case DA (2006) Automatic atom type and bond type perception in molecular mechanical calculations. J Mol Graph Model 25: 247-260. doi:10.1016/j.jmgm.2005.12.005

[26] Yang J, Roy A, Zhang Y (2013) Protein-ligand binding site recognition using complementary binding-specific substructure comparison and sequence profile alignment. Bioinformatics 29: 2588-2595. doi:10.1093/bioinformatics/btt447

[27] Macabeo APG, Cruz AJC, Narmani A, Arzanlou M, Babai-Ahari A, Pilapil LAE et al. (2020) Tetrasubstituted $\alpha$-pyrone derivatives from the endophytic fungus, Neurospora udagawae. Phytochem Lett 35: 147-151. doi:10.1016/j.phytol.2019.11.010

[28] Phukhamsakda C, Macabeo APG, Huch V, Cheng T, Hyde KD, Stadler M. (2019) Sparticolins A-G, biologically active oxidized spirodioxynaphthalene derivatives from the ascomycete Sparticola junci. J Nat Prod 82: 2878-2885. doi:10.1021/acs.jnatprod.9b00604 
[29] Mirza MU, Froeyen M (2020) Structural elucidation of SARS-CoV-2 vital proteins:

Computational methods reveal potential drug candidates against main protease, Nsp12

polymerase and Nsp13 helicase. J Pharm Anal 10: 320-328. doi:10.1016/j.jpha.2020.04.008

[30] Gao Y, Yan L, Huang Y, Liu F, Zhao Y, Cao L. et al. (2020) Structure of the RNA-

dependent RNA polymerase from COVID-19 virus. Science 368: 779-782.

doi:10.1126/science.abb7498

[31] White MA, Lin W, Cheng X (2020) Discovery of COVID-19 inhibitors targeting the SARSCoV2 nsp13 helicase. J Phys Chem Lett 11: 9144-9151. doi:10.1021/acs.jpclett.0c02421

[32] Encinar JA, Menendez JA (2020) Potential drugs targeting early innate immune evasion of SARS-Coronavirus 2 via 2'-O-methylation of viral RNA. Viruses 12: 525.

doi:10.3390/v12050525

[33] Krishnan DA, Sangeetha G, Vajravijayan S, Nandhagopal N, Gunasekaran K (2020)

Structure-based drug designing towards the identification of potential anti-viral for COVID-19 by targeting endoribonuclease NSP15. Inform Med Unlocked 20; 100392.

doi:10.1016/j.imu.2020.100392

[34] Wu C, Liu Y, Yang Y, Zhang P, Zhong W, Wang Y. et al. (2020) Analysis of therapeutic targets for SARS-CoV-2 and discovery of potential drugs by computational methods. Acta Pharm Sin B 10: 766-788. doi:10.1016/j.apsb.2020.02.008

[35] Wu A, Peng Y, Huang B, Ding X, Wang X, Niu P. et al. (2020) Genome Composition and divergence of the novel coronavirus (2019-nCoV) originating in China. Cell Host Microbe 27: 325-328. doi:10.1016/j.chom.2020.02.001 
[36] Henderson JA, Verma N, Shen J (2020) Assessment of proton-coupled conformational dynamics of SARS and MERS coronavirus papain-like proteases: Implication for designing broad-spectrum antiviral inhibitors. J Chem Phys 153: 115101. doi:10.1063/5.0020458

[37] Verma N, Henderson JA, Shen J (2020) Proton-coupled conformational activation of SARS Coronavirus main proteases and opportunity for designing small-molecule broad-spectrum targeted covalent inhibitors. J Am Chem Soc 142: 21883-21890. doi:10.1021/jacs.0c10770

[38] Shereen MA, Khan S, Kazmi A, Bashir N, Siddique R (2020) COVID-19 infection: Origin, transmission, and characteristics of human coronaviruses. J Adv Res 24: 91-98. doi:10.1016/j.jare.2020.03.005

[39] Chen J, Malone B, Llewellyn E, Grasso M, Shelton PMM, Olinares PDB et al. (2020) Structural basis for helicase-polymerase coupling in the SARS-CoV-2 replication-transcription complex. Cell 182: 1560-1573. doi:10.1016/j.cell.2020.07.033

[40] Rosas-Lemus M, Minasov G, Shuvalova L, Inniss NL, Kiryukhina O, Brunzelle J. et al. (2020) High-resolution structures of the SARS-CoV-2 2'-O-methyltransferase reveal strategies for structure-based inhibitor design. Sci Signal 13. doi:10.1126/scisignal.abe1202

[41] Bhardwaj K, Sun J, Holzenburg A, Guarino LA, Kao CC (2006) RNA recognition and cleavage by the SARS coronavirus endoribonuclease. J Mol Biol 361: 243-256. doi:10.1016/j.jmb.2006.06.021

[42] Deng X, Hackbart M, Mettelman RC, O'Brien A, Mielech AM, Yi G, et al. (2017) Coronavirus nonstructural protein 15 mediates evasion of dsRNA sensors and limits apoptosis in macrophages. Proc Natl Acad Sci USA 114: E4251-E4260. doi:10.1073/pnas.1618310114

[43] Fernandez RAT, Quimque MTJ, Notarte KIR, Manzano JAH, Pilapil DYH, de Leon VNO, San Jose JJP, Villalobos OA, Macabeo APG (2021) Myxobacterial depsipeptide chondramides 
interrupt SARS-CoV-2 entry by targeting its broad, cell tropic spike protein: Antagonistic prospects for anti-COVID-19 drug discovery [pre-print]. ChemRxiv. doi:10.26434/chemrxiv.14043641.v1.

[44] Könnyü B, Sadiq SK, Turányi T, Hírmondó R, Müller B, Kräusslich H. et al. (2013) Gag-Pol processing during HIV-1 virion maturation: A systems biology approach. Plos Comput Biol 9: e1003103. doi:10.1371/journal.pcbi.1003103

[45] Subbaraman N (2020) Who gets a COVID vaccine first? Access plants are taking shape Nature 585: 492-493. doi:10.1038/d41586-020-02684-9

[46] He Z, Xia W, Chen J (2008) Isolation and structure elucidation of phenolic compounds in Chinese olive (Canarium album L.) fruit. Eur Food Res Technol 226: 1191-1196. doi:10.1007/s00217-007-0653-5

[47] Emade Kwene C, Tih AE, Abderamane B, Ghogomu RT (2020) Two new phenolic glycosides from the leaves of Garcinia epunctata Stapf. Z Naturforsch C J Biosci 75: 51-56. doi:10.1515/znc-2018-0217

[48] Singh B, Singh JP, Kaur A, Singh N (2018) Phenolic compounds as beneficial phytochemicals in pomegranate (Punica granatum L.) peel: A review. Food Chem 261: 75-86. doi:10.1016/j.foodchem.2018.04.039

[49] Acuña UM, Figueroa M, Kavalier A, Jancovski N, Basile MJ, Kennelly EJ (2010) Benzophenones and biflavonoids from Rheedia edulis. J Nat Prod 73: 1775-1779. doi:10.1021/np100322d

[50] Shrestha S, Park J-H, Lee D-Y, Cho J-G, Seo W-D, Kang HC. et al. (2012) Cytotoxic and neuroprotective biflavonoids from the fruit of Rhus parviflora. J Appl Bio Chem 55: 557562. doi:10.1007/s13765-012-2090-9 
[51] Zhang GG, Jing Y, Zhang HM, Ma EL, Guan J, Xue FN. et al. (2012) Isolation and cytotoxic activity of selaginellin derivatives and biflavonoids from Selaginella tamariscina. Planta Med 78: 390-392. doi:10.1055/s-0031-1298175

[52] McMahon JB, Currens MJ, Gulakowski RJ, Buckheit RW, Jr Lackman-Smith C, Hallock YF. et al. (1995) Michellamine B, a novel plant alkaloid, inhibits human immunodeficiency virusinduced cell killing by at least two distinct mechanisms. Antimicrob Agents Chemother 39: 484488. doi:10.1128/aac.39.2.484

[53] Senanayake SL (2020) Overcoming nonstructural protein 15-nidoviral uridylate-specific endoribonuclease (nsp15/NendoU) activity of SARS-CoV-2. Future Drug Discov 2. doi:10.4155/fdd-2020-0012

[54] Doak BC, Over B, Giordanetto F, Kihlberg J (2014) Oral druggable space beyond the rule of 5: Insights from drugs and clinical candidates. Chem Biol 21: 1115-1142. doi:10.1016/j.chembiol.2014.08.013

[55] Tyagi M, Begnini F, Poongavanam V, Doak BC, Kihlberg J (2020) Drug syntheses beyond the rule of 5. Chemistry 26: 49-88. doi:10.1002/chem.201902716

[56] Daina A, \& Zoete V (2016) A BOILED-Egg to predict gastrointestinal absorption and brain penetration of small molecules. ChemMedChem 11: 1117-1121. doi:10.1002/cmdc.201600182 